\title{
pH CONTROL IN NITRATE UPTAKE STUDIES WITH EXCISED ROOTS*
}

\author{
by J. F. PARR ** and A. G. NORMAN ***
}

\section{INTRODUCTION}

More attention has been given to cation uptake mechanisms of root systems than to the concurrent process of anion uptake, even though such major nutrient elements as nitrogen, phosphorus, and sulfur ordinarily enter the root as anions. Short-term experiments with excised roots provide valuable information about ion uptake and accumulation by plant roots ${ }^{2}$. Excised roots often lend themselves better to the determination of uptake rates than when intact plants are employed, since the complicating influence of stems and leaves is eliminated.

When excised roots are placed in a single salt solution, the cationic and anionic components are usually absorbed at different rates resulting in rapid $\mathrm{pH}$ changes which, if not controlled, could greatly influence the uptake mechanisms ${ }^{5}$. Hoagland and Broyer ${ }^{2}$ observed that anion absorption may be markedly accelerated by a lowering of the $\mathrm{pH}$ of the medium and cation $\mathrm{ab}$ sorption by increasing the $\mathrm{pH}$. Van den Honert and Hooymans ${ }^{3}$ clearly demonstrated the profound influence of $\mathrm{pH}$ on the rate of $\mathrm{NO}_{3}{ }^{-}$absorption by maize roots, and this has been confirmed by other workers.

A procedure for close control of $\mathrm{pH}$ in cation-uptake studies, involving periodic additions of an anionic exchange resin in the

\footnotetext{
* Contribution from the Plant Nutrition Laboratory, Department of Botany, The University of Michigan, paper number 39. This work was supported by research grant GM-07339-02 from the National Institutes of Health, U. S. Public Health Service.

** Research Associate, The University of Michigan, now microbiologist, Division of Agricultural Development, Tennessee Valley Authority, Wilson Dam, Alabama.

**** Professor of Botany, The University of Michigan.
} 
$\mathrm{OH}^{-}$form, was recently reported by Parr and Norman ${ }^{7}$. This paper is an extension of this principle to studies on the uptake of an anion such as $\mathrm{NO}_{3}^{-}$by excised barley roots.

\section{METHODS}

\section{Preparation and treatment of excised roots}

Excised barley roots (Hordeum Vulgare L., var. Atlas 54) from 6-day-old seedlings were used throughout this study. The method of culture and treatment was exactly as described by Parr and Norman ${ }^{7}$ in which barley seedlings were grown in mass culture in an aerated solution of $7.5 \times 10^{-5} \mathrm{M}$ $\mathrm{CaSO}_{4}$ and $2.5 \times 10^{-5} \mathrm{MgSO}_{4}$. After excision, the roots were rinsed several times with cold distilled water and the excess water removed in a basket centrifuge. Fresh weight samples $(7.5 \mathrm{~g})$ of root material were placed in polystyrene vessels containing $200 \mathrm{ml}$ of either $\mathrm{KNO}_{3}$ or $\mathrm{Ca}\left(\mathrm{NO}_{3}\right)_{2}$ at concentrations ranging from $5 \times 10^{-4} \mathrm{~N}$ to $2 \times 10^{-3} \mathrm{~N}$. Solutions were aerated continuously through special manifolds fitted with 0.015 -inch $\mathrm{r}$. D. polyethylene tubing.

In one series of experiments involving the absorption of $\mathrm{NO}_{3}{ }^{-}$from $\mathrm{Ca}\left(\mathrm{NO}_{3}\right)_{2}$ solutions, the exchange sites on the roots were initially saturated with $\mathrm{Ca}^{++}$by pretreatment for 10 minutes in a solution of $5 \times 10^{-4} \mathrm{M}$ $\mathrm{CaSO}_{4}$. After being allowed to drain for one minute, and without rinsing, the root samples were transferred to the $\mathrm{Ca}\left(\mathrm{NO}_{3}\right)_{2}$ solutions to begin the $\mathrm{NO}_{3}{ }^{-}$ absorption study. The justification for this pretreatment will be discussed later.

Small samples of the ambient solutions were withdrawn periodically during the absorption period to determine the rate of $\mathrm{NO}_{3}{ }^{-}$-uptake. All experiments were conducted at $25^{\circ} \mathrm{C}$.

\section{Preparation and use of resin for control of $p H$}

The $\mathrm{pH}$ of salt solutions in these experiments, unless otherwise specified, were maintained close to 5.5 during the absorption period by periodic additions of small measured volumes of analytical grade Amberlite IR-120 (sulfonic acid type), supplied in the $\mathrm{H}^{+}$form by the Rohm and Haas Company Philadelphia, Pennsylvania. Prior to use the resin was thoroughly washed with distilled water and, after repeated washing and settling to remove finer particles, the bead diameter of the resin ranged from 0.45 to $0.60 \mathrm{~mm}$.

The resin was used in a moist state after excess water had been removed on a Buchner funnel. The capacity of the resin to lower the $\mathrm{pH}$ of various nitrate salt solutions ranging in concentration from $5 \times 10^{-4} \mathrm{~N}$ to $2 \times 10^{-3}$ $N$, in the absence of roots, was determined by observing the shift in $\mathrm{pH}$ after successive additions of $0.05 \mathrm{cc}$ moist resin. After each addition an equilibration period of 30 minutes was allowed. All pH changes were followed with a Beckman Zeromatic $\mathrm{pH}$ meter.

Throughout the absorption period $\mathrm{pH}$ was maintained near 5.5 by addition 
of small increments of resin directly to the bottoms of the containers after gently pulling the roots to one side. With $7.5 \mathrm{~g}$ of roots in $200 \mathrm{ml}$ of $\mathrm{Ca}\left(\mathrm{NO}_{3}\right)_{2}$ solution 2 or 3 resin additions, each about $0.015 \mathrm{~g}$ dry weight, were effective in providing $\mathrm{pH}$ control during a 6 -hour absorption period.

\section{Nitrate determinations}

The uptake of $\mathrm{NO}_{3}-$ by excised roots was determined by the difference between the initial and final $\mathrm{NO}_{3}{ }^{-}$concentration of the ambient solutions using the phenoldisulfonic acid method ${ }^{4}$. Color densities were read in an Evelyn colorimeter at $420 \mathrm{~m} \mu$.

\section{RESULTS AND DISCUSSION}

The initial experiments were conducted with different nitrate salts, involving both monovalent and divalent cations, in order to determine the extent of the $\mathrm{pH}$ changes in the presence of excised roots, without $\mathrm{pH}$ control. In the case of four divalent salts ( $\mathrm{Ca}, \mathrm{Mg}$, $\mathrm{Sr}, \mathrm{Ba}$ ) the $\mathrm{pH}$ trend was quite similar and is typified by the $\mathrm{Ca}$ $\left(\mathrm{NO}_{3}\right)_{2}$ curve in the upper portion of Figure 1. On placing the excised roots in the salt solutions, an initial rapid downward deflection in $\mathrm{pH}$ occurred, due mainly to an immediate adsorption of the cationic component by exchange sites on the roots ${ }^{6}$. The downward deflection from the initial solution $\mathrm{pH}$ of 5.5 was complete in 15 to 20 minutes and after a short stationary period lasting for 5 to 10 minutes a steady increase in $\mathrm{pH}$ was observed. This increase in $\mathrm{pH}$ continued for all the divalent salts throughout the rest of the absorption period, suggesting a more rapid rate of $\mathrm{NO}_{3}^{-}$uptake than of the cationic component. Similar observations have been reported by Hoagland and Broyer ${ }^{2}$.

In the case of the monovalent salts $\left(\mathrm{Na}, \mathrm{K}, \mathrm{NH}_{4}\right)$, the trend was somewhat different and is typified by the $\mathrm{KNO}_{3}$ curve in the upper portion of Figure 1. The rapid initial downward $\mathrm{pH}$ deflection was somewhat greater than in the divalent salt solutions and continued longer. In the monovalent salt solutions a minimal $\mathrm{pH}$ value of 4.3 was attained after about one hour and maintained at that level, indicating approximately equal rates of absorption of the anionic and cationic components at that $\mathrm{pH}$.

The $\mathrm{pH}$ changes in these systems can be overcome to a large extent by using small toot samples in large volumes of salt solution, i.e. smaller root-to-solution ratios 5 ; however, this necessitates root 
ashing to determine ion uptake. A higher root-to-solution ratio allows the determination of ion uptake directly by following the depletion of the ion in solution.

These observations of $\mathrm{pH}$ trends made it evident that divalent nitrate salts would be preferable in controlled $\mathrm{pH}$ experiments at rather high root-to-solution ratios, because after the initial downward deflection due to ion exchange adsorption on roots, there was a progressive upward trend with time. An effective control procedure would then allow experiments to be carried out within physiologically desirable $\mathrm{pH}$ limits. When $\mathrm{Ca}\left(\mathrm{NO}_{3}\right)_{2}$ was used during the $\mathrm{ab}-$ sorption period, the initial downward shift in $\mathrm{pH}$ was effectively minimized by a 10-minute pretreatment of the excised roots with $5 \times 10^{-4} M \mathrm{CaSO}_{4}$. Although the exchange sites on the root are at least partially satisfied by $\mathrm{Ca}^{++}$and $\mathrm{Mg}^{++}$from the salt solutions used in the root-culture procedure, without this pretreatment there was an initial deflection from $\mathrm{pH} 5.5$ to 4.8 (Fig. 1, upper curve);

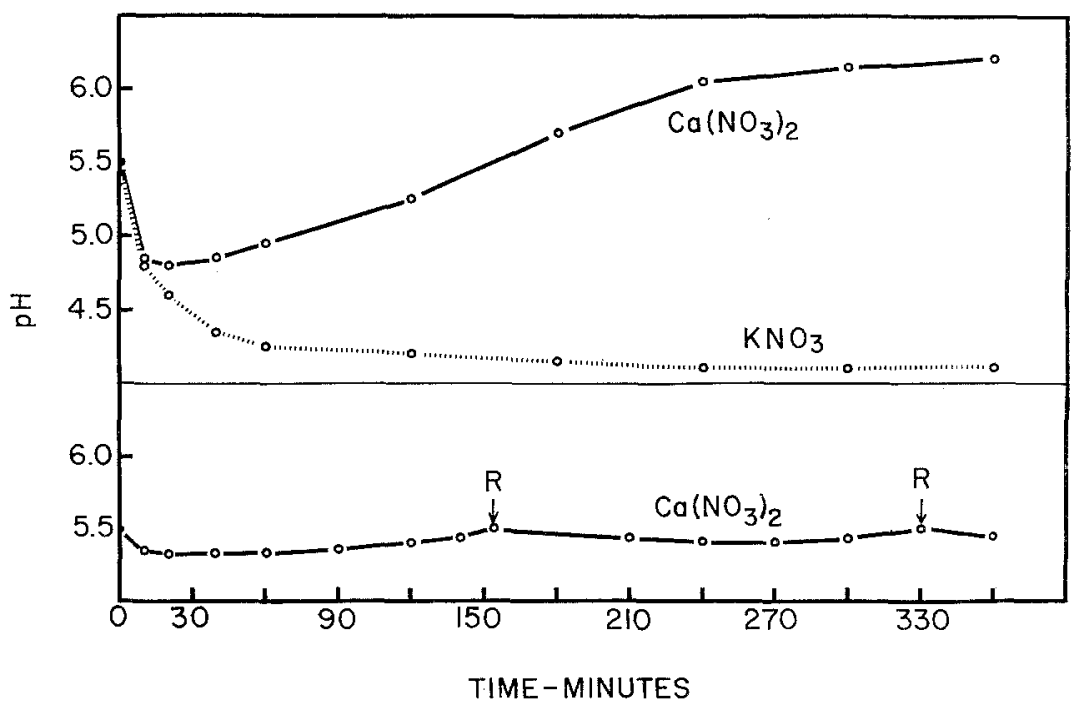

Fig. 1. Upper portion: Changes in $\mathrm{pH}$ as a result of unequal rates of absorption of the anionic and cationic components of two nitrate salts by excised barley roots. Lower portion: Control of $\mathrm{pH}$ during salt absorption by excised barley roots. Roots pretreated with $5 \times 10^{-4} \mathrm{M} \mathrm{CaSO}_{4}$ for 10 minutes, and $\mathrm{pH}$ of solutions maintained close to 5.5 by two additions $(R)$ of Amberlite exchange resin $\mathrm{IR}-120 \mathrm{H}^{+}$.

All experiments involved $7.5 \mathrm{~g}$ roots, fresh weight, in $200 \mathrm{ml} 2 \times 10^{-3} \mathrm{~N}$ nitrate solution at $25^{\circ} \mathrm{C}$ for 6 hours. Each point is the mean of 4 replicates. 
but if the exchange sites were virtually saturated with $\mathrm{Ca}^{++}$, the minimum reached was only 5.35 (Fig. 1, lower curve). Since $\mathrm{SO}_{4}=$ apparently does not compete with $\mathrm{NO}_{3}-$ for specific active sites during the absorption process ${ }^{1}$, the small amount of residual $\mathrm{SO}_{4}=$ left on the roots after pretreatment does not interfere with subsequent $\mathrm{NO}_{3}-$ absorption.

In controlled-pH studies, therefore, pretreatment of excised roots with $\mathrm{CaSO}_{4}$ was practiced, followed by periodic additions of Amberlite $\mathrm{IR}-120 \mathrm{H}^{+}$to check the upward shift in $\mathrm{pH}$. In our studies we have used the resin procedure successfully for control of $\mathrm{pH}$ of solutions ranging from 5 to 7 . The lower curve of Figure 1 shows the effectiveness of this resin to control $\mathrm{pH}$ within rather narrow limits. Differences in $\mathrm{pH}$ between replicates controlled by resin did not exceed $0.2 \mathrm{pH}$ units at any time. In the $\mathrm{NO}_{3}{ }^{-}$-uptake studies reported here with $2 \times 10^{-3} \mathrm{~N} \mathrm{Ca}\left(\mathrm{NO}_{3}\right)_{2}$, the $\mathrm{pH}$ was maintained near 5.5. using the resin procedure and excellent reproducibility was observed between replicates as shown in Table 1. In these experiments $\mathrm{pH}$ was effectively controlled at 5.5 with two small resin additions, each about $0.015 \mathrm{~g}$ dry weight, during a six-hour period. The lower curve of Figure 1 illustrates that the resin functions as an effective buffer in which the exchange between the $\mathrm{H}^{+}$of the resin and the excess $\mathrm{Ca}^{++}$of the solution extends over a substantial period of time.

The effectiveness of $\mathrm{pH}$ control on the course of nitrate uptake by excised barley roots from a $2 \times 10^{-3} \mathrm{~N} \mathrm{Ca}\left(\mathrm{NO}_{3}\right)_{2}$ solution is shown in Table 1 . As the $\mathrm{pH}$ increased in the uncontrolled solutions the uptake rate declined so that at 6 hours the cumulative uptake was only 77 per cent of that from solutions that were maintained near $\mathrm{pH}$ 5.5. This difference developed largely in the final two hours during which period tho $\mathrm{pH}$ of the two series diverged markedly.

TABLE 1

\begin{tabular}{|c|c|c|}
\hline $\begin{array}{c}\text { Effect of } \mathrm{pH} \text { control on nitrate uptake by excised barley roots. } 7.5 \text { g roots, fresh } \\
\text { weight, in } 200 \mathrm{ml} 2 \times 10^{-3} \mathrm{~N} \mathrm{Ca}\left(\mathrm{NO}_{3}\right)_{2} .4 \mathrm{H}_{2} \mathrm{O} \text { at } 25^{\circ} \mathrm{C} \text { for } 6 \text { hours }\end{array}$ \\
\hline \begin{tabular}{c|c|c} 
Hours after \\
start of uptake
\end{tabular} & Milligrams of nitrate absorbed * and pH reading \\
\hline 2 & $\mathrm{pH}$ controlled with resin & No pH control \\
\hline 4 & $0.86 \pm 0.04(5.40)$ & $0.85 \pm 0.02(5.65)$ \\
6 & $1.70 \pm 0.10(5.40)$ & $1.58 \pm 0.06(5.90)$ \\
\hline
\end{tabular}

* Mear and standard deviation of 4 repicates, with $\mathrm{pH}$ values in parentheses. 
There are several advantages in the use of resin for the control of $\mathrm{pH}$. It provides for the control of $\mathrm{pH}$ by addition of $\mathrm{H}^{+}$without an accompanying anion which might interfere with the absorption of the anion under study. In the present studies attempts to control pH with $\mathrm{H}_{2} \mathrm{SO}_{4}$ were rather unsuccessful since very dilute solutions had the effect of diluting the $\mathrm{NO}_{3}{ }^{-}$-concentration, while more concentrated $\mathrm{H}_{2} \mathrm{SO}_{4}$ caused very abrupt deflections. The resin method allows anion uptake studies to be conducted at high root-to-solution ratios with the distinct advantage of permitting a direct determination of anion absorption by noting differences in anion concentration between initial and final ambient solutions.

\section{SUMMARY}

In the investigation of $\mathrm{NO}_{3}^{-}$uptake by excised roots, $\mathrm{pH}$ of salt solutions can be effectively controlled by periodic additions of a cation exchange resin, Amberlite IR-120, in the $\mathrm{H}^{+}$form. This method of $\mathrm{pH}$ control provides for the addition of $\mathrm{H}^{+}$to systems without an accompanying anion which might influence the absorption of $\mathrm{NO}_{3}{ }^{-}$. The resin appeared to provide a favorable buffering capacity during an extended period and the method was especially useful for $\mathrm{NO}_{3}^{-}$uptake studies conducted at high root-to-solution ratios.

Received November 11, 1963

\section{LITERATURE CITED}

1 Epstein, E., Mutual effects of ions in their absorption by plants. "IV Simposio Internat. di Agrochim'. Pisa-Firenze 222-251 (1962).

2 Hoagland, D. R. and Broyer, T. C., Hydrogen-ion effects and the accumlation of salt by barley roots as influenced by metabolism. Am. J. Botany 27, 173-185 (1940).

3 Honert, T. H. van den, and Hooymans, J. J. M., On the absorption of nitrate by maize in water culture. Acta Bot. Neerl. 4, 376-384 (1955).

4 Jackson, M. L., Soil Chemical Analysis. Prentice Hall Inc., Englewood Cliffs, N. J. (1958).

5 Jacobșon, L., Hannapel, R. J, Schaedle, M., and Moore, D. P., Effect of root to solution ratio in ion absorption experiments. Plant Physiol. 36, 62-65 (1961).

6 Laties, G. G., Active transport of salt into plant tissue. Ann. Rev. P1. Physiol. 10, $87-112(1959)$.

7 Parr, J. F. and Norman, A. G., A procedure for control of $\mathrm{pH}$ in cation uptake studies with excised barley roots. Soil Sci. Soc. Am. Proc. 27, 531-534 (1963). 